\title{
Activation of NK cells and disruption of PD-L1/PD-1 axis: two different ways for lenalidomide to block myeloma progression
}

\author{
Massimo Giuliani ${ }^{1}$ Bassam Janji,** and Guy Berchem ${ }^{1,2, *}$ \\ ${ }^{1}$ Laboratory of Experimental Cancer Research, Department of Oncology, Luxembourg Institute of Health, Luxembourg City, \\ Luxembourg \\ 2 Department of Hemato-Oncology, Centre Hospitalier du Luxembourg, Luxembourg City, Luxembourg \\ * These authors have equally contributed to this work \\ Correspondence to: Bassam Janji, email: bassam.janji@lih.lu \\ Keywords: lenalidomide, multiple myeloma, NK cells, PD-L1/PD-1, immunotherapy \\ Received: July 07, $2016 \quad$ Accepted: January 16, $2017 \quad$ Published: February 09, 2017
}

ABSTRACT

Natural Killer (NK) cells play a critical role against tumor cells in hematological malignancies. Their activating receptors are essential in tumor cell killing. In Multiple Myeloma (MM) patients, NK cell differentiation, activation and cytotoxic potential are strongly impaired leading to $M M$ escape from immune surveillance in tissues and bone marrow. Mechanisms used by MM to affect NK cell functions are mediated by the release of soluble factors, the expression of activating and inhibitory NK cell ligands, and the expression of immune check-point inhibitors. Lenalidomide represents an efficient clinical approach in MM treatment to improve patients' survival. Lenalidomide does not only promotes tumor apoptosis, but also stimulates $T$ and NK cells, thereby facilitating NK-mediated tumor recognition and killing. This occurs since Lenalidomide acts on several critical points: stimulates $\mathrm{T}$ cell proliferation and cytokine secretion; decreases the expression of the immune check-point inhibitor Programmed Death-1 (PD-1) on both T and NK cells in MM patients; decreases the expression of both PD-1 and PD-L1 on MM cells; promotes MM cell death and abrogates MM/stromal microenvironment cross-talk, a process known to promote the MM cell survival and proliferation. This leads to the inhibition of the negative signal induced by PD-1/PDL1 axis on NK cells, restoring NK cell cytotoxic functions. Given the importance of an effective immune response to counteract the MM progression and the promising approaches using anti-PD-1/PD-L1 strategies, we will discuss in this review how Lenalidomide could represent an adequate approach to re-establish the recognition against MM by exhausted NK cell.

\section{NK CELL-MEDIATED TUMOR SURVEILLANCE AND MULTIPLE MYELOMA}

NK cells play a critical role in cancer surveillance, and their cytotoxic functions are regulated by a balance between the expression of activating and inhibitory receptors [1-4]. Activating receptors includes Natural Cytotoxic Receptors (NCRs), such as NKp30, NKp44 and NKp46, NKG2D, DNAX Accessory Molecule-1 (DNAM-1) and several co-stimulatory receptors such as LFA-1, NKp80 and CD244 (2B4). The main group of inhibitory receptors are the Killer Inhibitory Receptors (KIRs) and NKG2A, specific for Major Histocompatibility
Complex (MHC) class I molecules. Activating receptors initiate granule-dependent killing where Perforin and Granzymes are released by NK cells followed by synapse formation with the target. NK cells play also a critical role in autologous stem cell transplantation in several hematological malignancies, as described in the section [5-10]. Advanced findings have demonstrated that the number of NK cells isolated from patients with hematological malignancies including Multiple Myeloma (MM) is strongly decreased and their cytotoxic functions are seriously impaired [11-18]. An overview of pathogenesis and therapeutic strategies in $\mathrm{MM}$ is reviewed in the following references [19-22]. Importantly, NK cells isolated from MM patients display a significant down-regulation of CD16, DNAM-1 and 2B4/CD244 
expression, associated with impaired killing abilities [14$18,23,24]$. Recently it has been shown that NK cells isolated from MM patients display decreased expression of the activating receptor CD161 and an increased expression of KIRs, which contribute to the impairment of NK cell cytotoxic functions $[25,26]$.

\section{MECHANISMS USED BY MM CELLS TO SUPPRESS NK CELL FUNCTIONS}

\section{Immune check-point inhibitors: role of PD-L1/ PD-1 axis}

Hematological malignancies develop several strategies to impair the immune response or to modulate the tumor microenvironment. Acute Myeloid Leukemic (AML) cells express several co-stimulatory molecules such as CD80 and CD86 to interact with CTLA4 (cytotoxic T-cell antigen-4)-expressing $\mathrm{T}$ cells [27]. In addition, AML cells express immune inhibitory check-points and HLA class I molecules, which contribute to the antitumor response exhaustion and immune escape [27, 28]. Different approaches have been proposed to harness the anti-tumor response against AML cells, such as antigentargeted therapies, inhibitory check-points modification and cytokine therapies [27]. Similarly, it has been shown that malignant cells from Chronic Lymphocytic Leukemia (CLL) patients impair NK cell cytotoxic functions, thus facilitating NK cell anergy and tumor progression [29]. In addition, compared to healthy donors, CLL cells secrete elevated amount of soluble NK activating ligands, which contribute to the impairment of NK killing activity [30]. Furthermore, it has been also shown that stromal cells, nurse-like cells (NLC) and follicular dendritic cells (FDC) in the tumor microenvironment play a major role in CLL progression and drug resistance [29, 31]. In the last decade, several immunotherapies have been validated in CLL patients, including Immunomodulatory drugs, monoclonal antibodies, Bi-Specific $\mathrm{T}$ cell Engagers $\left(\mathrm{BiTE}^{\circledR}\right)$, immune check-point inhibitors and chimeric antigen receptor (CAR) T cells [32].

Dendritic cells (DC) in MM patients display decreased co-stimulatory molecules expression and functions, and therefore are in an immature state. These immature DC are responsible for affected T cell activation and migration [26, 33, 34]. In addition, Sponaas et al., reported that DC and plasma cells in myeloma patients express PD-L1 (Programmed death ligand 1), which is correlated with an impairment of anti-tumor response [35]. Interestingly, it has been reported that DC play a dual opposite role as promoter of CD8 + T cells-mediated MM cell killing and as facilitator of MM cell resistance to CD8(+) T-cell killing [36]. Additionally, a positive effect in $\mathrm{DC}$ activation mediated by Lenalidomide treatment has been observed in both MM patients [37] and murine MM model [38]. Macrophages represent an important population in the MM microenvironment [39]. MM cells secrete inflammatory factors to recruit macrophages in the tumor site; in turn, macrophages are able to differentiate from M1 (classically activated, pro-inflammatory) to M2 (alternatively activated) phenotype, secreting factors to promote survival and drug resistance in MM cells [39, 40]. Interestingly, the stromal microenvironment promote this differentiation by secreting soluble factors such as CCL2 and IL-6 [41, 42]. Concerning the T cell subsets, change in CD8/CD4 ratio in $\mathrm{T}$ cells has been observed in MM patients, where most of $\mathrm{T}$ cells display reduced expression of co-stimulatory molecules, such as CD28, and increased expansion of Treg and Th17 subset, which in turn promotes MM cell growth $[33,34]$. Among these strategies, a critical role in MM progression is played by the secretion of soluble factors as Prostaglandin-2 (PGE2 ) and Transforming Growth Factor (TGF- $\beta$ ), or by the expression of immune check-point inhibitors [18, 33, 43-45]. Advanced findings have shown in fact that the immune check-point inhibitor PD-L1 play a major role in MM escape from immune cells [18, 33, 43, 46]. PDL1 can be expressed by solid tumors and hematological malignancies to inhibit $\mathrm{T}$ and NK cell functions and, paradoxically, its expression can be increased by the IFN- $\gamma$ secreted by immune cells, persisting its inhibitory effect [47-49]. In contrast to healthy plasma cells, those derived from MM patients express PD-L1 and therefore participate to the inhibition of Cytotoxic T Cells (CTL) proliferation and cytolytic functions [46, 50-56]. Notably, Wang et al., recently reported that $\mathrm{PD}-\mathrm{L} 1$ can be also found as soluble form in MM patients, which could represent a potential marker for diagnosis and therapy [57]. The PD-L1 receptor PD-1 is expressed on activated T and NK cells [58]. Triggering PD-1 blocks the activating cascade induced by the T-cell receptor (TCR) and the activating receptors on T cells and NK cells, respectively [59, 60]. PD-1 activates Src-homology 2-containing tyrosine phosphatase (SHP2 ), which interfere with PKC- $\theta$, PI3K, ERK and AKT activation, critical for $\mathrm{T}$ cell proliferation (for a detailed review see [59, 60]) (Figure 1a). Persistent expression of PD-1 in T cells leads not only to $\mathrm{T}$ cell exhaustion and an impaired $\mathrm{T}$ cell-mediated immunosurveillance, but also to the development of regulatory $\mathrm{T}$ cells (Treg) population [48, 61]. Similarly, PD-1-mediated SHP2 activation inhibits activating receptors-induced cytotoxicity, granule exocytosis and IFN- $\gamma$ secretion in NK cells [4, 48, 61] (Figure 1b). Recently, it has been reported that PD-1 microclusters can be found in the NK immunological synapse (NKIS), thus impairing NK cell recognition of target cells [62]. Interestingly, it has also been shown that cytokines such as IL-18 could up-regulate PD-1 expression on NK cells in the lymph nodes, thus promoting metastases dissemination of NK cell-dependent tumors [63]. It is noteworthy that PD-1 is absent on NK 
cells isolated from healthy donor but it is expressed on those from MM patients [50]. Furthermore, NK and $\mathrm{T}$ cells stimulated with an anti-PD-1 antibody CT-011 restored the cytolytic ability of NK to kill target cells [46, 50, 54, 55]. Additionally, clonal T cells in MM can be hypo-responsive and fail to respond to several cytokines $[64,65]$. Interestingly, these T-cell clones isolated from MM patients have normal TCR signaling but a defective p-SMAD pathway, which suppress cell proliferation. In particular, these T-cell clones displayed low levels of PD-1, which could explain their telomere-independent senescence $[64,65]$. These results point out to the fact that PD- $1^{\text {low }}$ T-cell clones fail to be fully activated by an antiPD-1 therapy in MM, leading to a partial response in MM patients $[65,66]$.

Advanced evidences demonstrate that BM stromal cells isolated from MM patients display several abnormalities, compared to healthy donors [67-69]. The consequence is an uncontrolled MM progression, survival, growth and drug resistance, associated with angiogenesis and tumor escape [19, 70-72]. In turn, MM cells induce stromal cells to promote a pro-angiogenic and an immuno-suppressive milieu. Interestingly, Ponzetta et al., have recently demonstrated that MM cells and tumor microenvironment influence NK cell trafficking in the bone marrow $(\mathrm{BM})$, impairing NK cell-mediated tumor recognition [73]. Mechanisms involved in this evasion are the down-regulation of CXCR3 and CXCR4 on NK cells and the up-regulation of chemokines secretion by the tumor microenvironment such as CXCL9 and CXCL10. Interestingly, MM cells cultured with stromal cells express high levels of PD-L1 $[71,74]$. The consequence is that PDL1-expressing MM cells interact with the PD-1 expressed by immune cells, thus affecting $\mathrm{T}$ and $\mathrm{NK}$ cell activation and supporting MM progression and immune-escape [50]. These results suggest that the PD-1/PD-L1 axis expressed on MM cells, stromal and immune cells, play a critical role not only in supporting MM progression and survival, but also in protecting cancer cells from effector cells [50].

\section{Activating NK ligands}

Another major mechanism used by MM cells to escape to NK cell-mediated attack is the modulation of the expression of NKG2D [MHC class I related chain A/B (MICA/B), UL16-binding proteins (ULBPs)] and DNAM1 (PVR and Nectin-2) ligands on their surface [3, 18, 75]. Notably, the down-regulation or the release of MICA expression facilitate tumor cell escape $[13,17,23$, 7681]. Furthermore, Jinushi and colleagues have shown that plasma cells from MM patients express low level of MICA at their surface and significant high level of soluble MICA (sMICA), whereas plasma cells from MGUS patients have opposite expression of MICA [82]. Consequently, sMICA could represent a prognostic factor in MM patients [81]. In addition, NK cells derived from MM patients displayed a reduced expression of $\mathrm{NKG} 2 \mathrm{D}$, but a large amount of sMICA in the patients' plasma. Interestingly sMICA was not correlated with the reduced expression of NKG2D on NK cells, suggesting that MM escape is promoted by a direct interaction between NK and MM cells, rather than by sMICA secreted by MM cells themselves [83].

Furthermore, the up-regulated expression of MHC class I molecules and the decreased expression of Fas have been described to protect MM cells from NK cell lysis [14, 16]. Importantly, in early stages of the MM pathogenesis, the escape from NK cells seems to be associated with a down-regulation of the activating ligands rather than an increase of inhibitory ligands. However, in late-stage, $\mathrm{MM}$ are rather protected from NK cell lysis by a high expression of HLA class I molecules [13, 14, 16, 26, 82].

\section{LENALIDOMIDE AS PROMISING STRATEGY TO RESTORE IMMUNE RESPONSE AND IMPROVE PATIENTS SURVIVAL}

\section{Lenalidomide and MM cells survival}

MM is a hematologic cancer characterized by an accumulation of terminally differentiated plasma cells in the BM $[21,84]$. Despite the use of several therapeutic strategies MM is still incurable disease and numerous patients relapse and/or develop resistance to current therapies. The choice of drug treatment depends on the tumor progression and the age of the patient. Strategies include, among others, (a) Bortezomib/Thalidomide/ Dexamethasone (VTD) in relapsed refractory myeloma, (b) Vincristine/Adriamycin/Dexamethasone (VAD) in patients which will receive Stem Cell Transplantation (SCT), (c) Melphalan/Prednisone combination in patients who are ineligible for an Autologous SCT, (d) Melphalan/ Prednisone/Thalidomide or (e) Bortezomib/Melphalan/ Prednisone [21, 84-88]. Interestingly, several groups reported that the number, the activation and the cytotoxic functions of NK cells are increased during and after SCT. This is associated with an overall survival in MM patients [5], even in T cell-depleted allografts $[6,89]$. In addition, following autologous SCT, NK cells display higher expression of CD57 and KIRs, compared to the same cell analyzed before or at later time points after SCT. Although these NK cells also strongly express KIR2DL2/3/ S2 and KIR3DL1, associated with a more immatures characteristics, they show granule exocytosis and secretion abilities [90]. In addition, Htut and colleagues showed that NK cells in MM patients undergoing hematopoietic cell transplantation (HCT) displayed a decreased expression of the TNF receptor OX40 (CD134) [91]. Interestingly, Lenalidomide treatment during and after SCT improved anti-myeloma activity (NCT00778752) [92, 93] by 
increasing the proliferation and NKp44 expression on NK cells [91, 92], which are associated with a significant down-regulation of CTLA-4 expression [91].

In the last decade new approaches such as IPH2102 (anti-KIR) mAb therapy and immune check-points inhibitors (ipilimumab (anti-CTLA-4) [48, 49, 94, 95] have made further progresses in solid tumors and hematological malignancies. However, their impact on MM cell functions and the NK/MM interaction has not been completely investigated. A similar argument could be used for other drugs such as the proteasome inhibitors Bortezomib and Carfilzomib (PR-171) and Histone Deacetylases inhibitors (HDACi), which have been demonstrated to improve antitumor response [12, 96, 97]. The survival rates of relapsed MM patients has been significantly improved since the introduction of Immunomodulatory drugs (IMiDs) including Thalidomide, Lenalidomide and more recently Pomalidomide [86, 97]. Thalidomide was described as anti-angiogenic, anti-tumor and immune modulatory agent affecting many cell types [97-100]. These properties have contributed to re-approved Thalidomide by the Food and Drug Administration (FDA) for MM treatment. Similarly, Pomalidomide (Pomalyst ${ }^{\mathrm{TM}}$ ) has been approved by FDA in 2013 due to its anti-tumor properties characterized

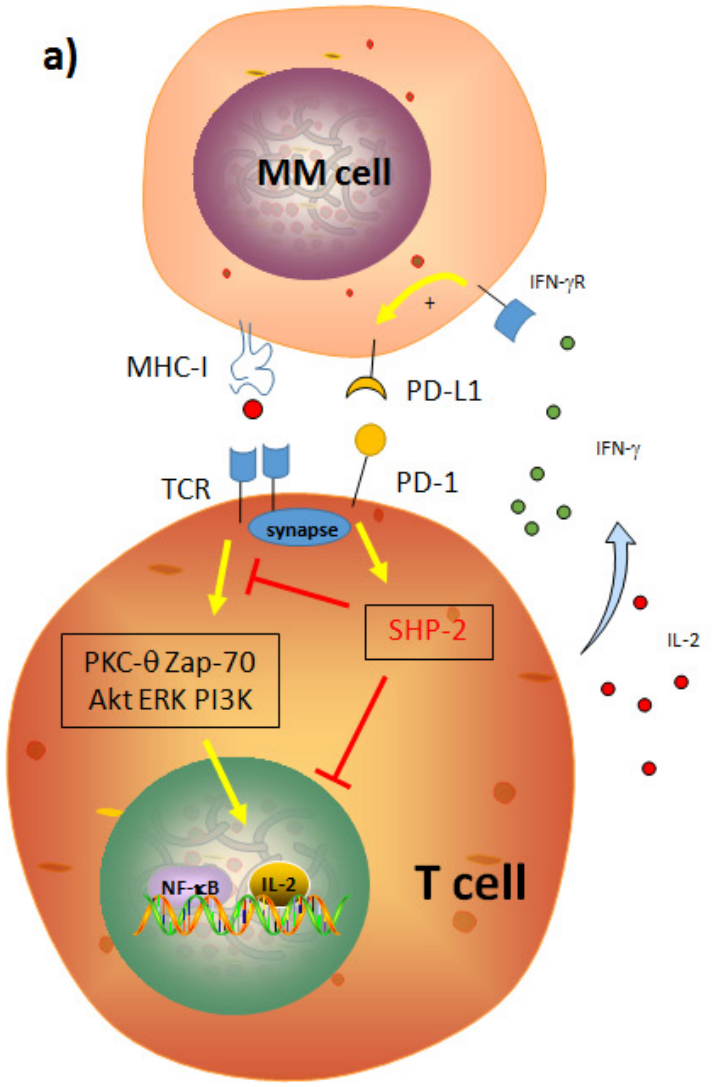

by increasing NK cell activation, down-regulating osteoclastogenesis and inhibiting the interaction between stromal and myeloma cells [96, 97, 101]. The introduction of Lenalidomide (CC-5013, Revlimid ${ }^{\circledR}$ ) as new clinical approach improved the median survival of MM patients, even in those developing resistance and disease relapse [102-105]. Following its approval in 2006 by FDA in MM treatment, a plethora of clinical trials registered in www. clinicaltrials.gov demonstrated a strong anti-tumor effect of Lenalidomide when administrated alone or combined with others drugs [22, 102, 103, 106-108]. Notably, Lenalidomide displays anti-tumor abilities on malignant plasma cells, affecting multiple mechanisms involved in tumor development and survival [97]. For example, Lenalidomide display anti-osteoclastogenic properties and induces cell cycle arrest and increases the expression of Cyclin-dependent kinase (CDK) inhibitors on MM cells, thus inhibiting their proliferation and promoting their apoptosis [97, 109-111] (Figure 2). Recent findings also show that Lenalidomide partially reversed the exhaustion of effector cells promoted by stromal microenvironment Myeloid-derived suppressor cells (MDSC) [112] and DC [35] (Figure 2). Lenalidomide also acts on tumor microenvironment, by disrupting the $\mathrm{MM} /$ stromal cells

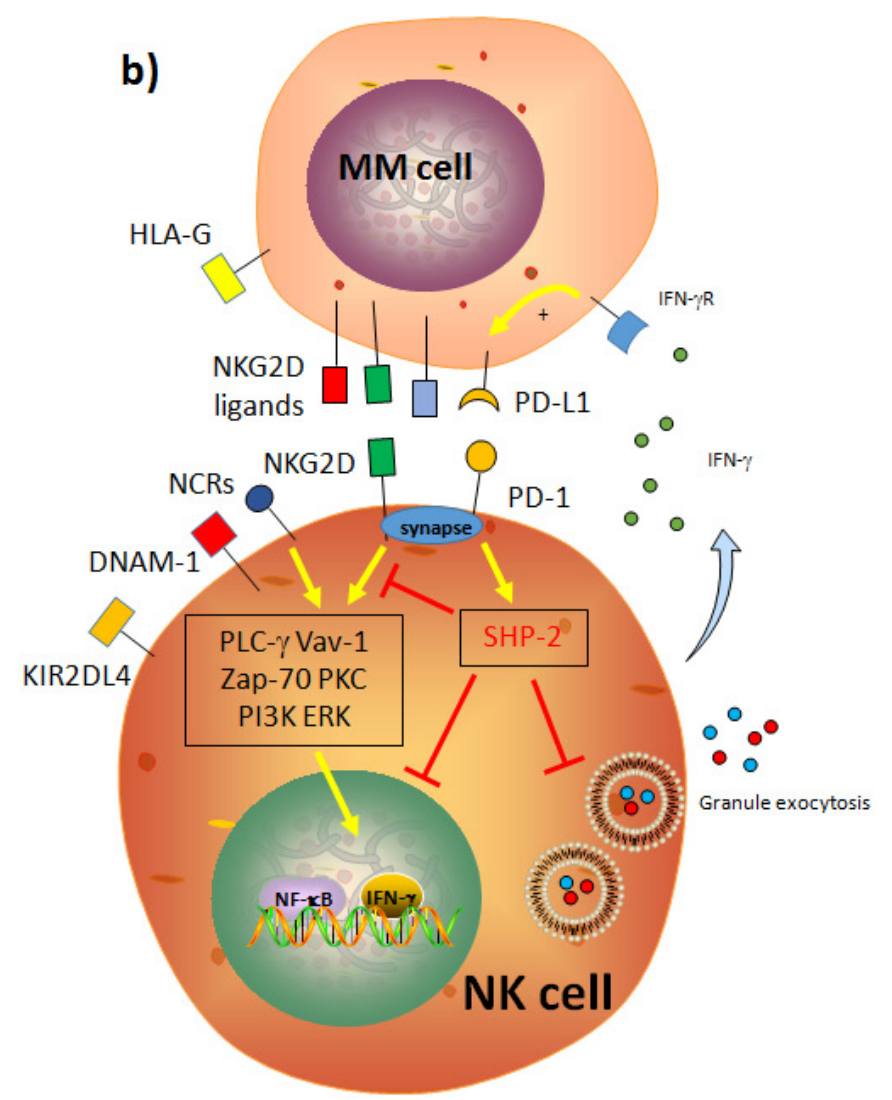

Figure 1: Schematic representation of the impact of the PD-1/PD-L1 axis on $\mathrm{T}$ and NK cell cytotoxic functions. a. PD-1 blocks the activating cascade induced by the T-cell receptor (TCR) and the activating receptors in T cells and NK cells, respectively. PD-1 activates Src-homology 2-containing tyrosine phosphatase (SHP-2), which interfere with PKC- $\theta$, PI3K, ERK and AKT activation and signaling, critical for T cell proliferation. b. Similarly, PD-1-mediated SHP-2 activation inhibits PKC- $\theta$, PI3K and ERK activation, critical for NK cell functions. This leads to an impaired proliferation, cytotoxicity, granule exocytosis and IFN- $\gamma$ secretion in NK cells. 
cross-talk. This leads to a decreased secretion of proangiogenic and anti-inflammatory molecules, and downregulated expression of both $\mathrm{PD}-1$ and $\mathrm{PD}-\mathrm{L} 1$ expression in MM cells, constitutively expressed or induced by the stromal microenvironment [50, 54, 74]. These results highlight the critical role of BM microenvironment on MM progression, and the importance to develop antitumor approaches based on the PD-1/PD-L1 complex $[50,71,74]$. The positive impact of PD-1/PD-L1 axis in $\mathrm{MM}$ eradication has been also confirmed in vivo in a myeloma murine model (5T33) [54, 113]. Authors demonstrated that PD-1/PD-L1 blockade with a PD-L1specific $\mathrm{Ab}$ elicits rejection of a murine myeloma when combined with lymphodepleting irradiation [113]. In addition, $\mathrm{T}$ cells from myeloma-bearing mice up-regulate their PD-1 expression in response to multiple myeloma [54]. Interestingly, these PD-1-expressing CD8 ${ }^{+} \mathrm{T}$ cells, although activated, do not secrete inflammatory cytokines and they undergo to apoptosis. It has been reported that these lymphocyte express TIM-3 (T-cell immunoglobulin and mucin-domain containing-3), a marker synonimous of cell exhaustion [114, 115]. Of note, the blockade of PD-L1 during vaccine administration resulted in improved vaccine efficacy. Together, these results are very interesting since, as discussed above, Lesokhin et al., shown that T-cell clones PD- ${ }^{\text {low }}$ lead to a partial response in MM patients with an anti-PD-1 therapy [66]. The positive effect of Lenalidomide on MM killing has also been recently reported by Ray and colleagues. They demonstrated that IMiDs combined with ACY-1215 (Ricolinostat), Bortezomib, anti-PD-L1 antibody or Tolllike receptor agonists strongly increased the anti-tumor response [116]. In this case, Lenalidomide enhanced the effect of PD-1/PD-L1 blocking on NK cell-mediated tumor killing. Interestingly, the positive combination of Pembrolizumab/Dexamethasone with Lenalidomide [117] and Pomalidomide has been also reported in MM patients [118] (NCT02289222). A summary of ongoing and completed Clinical Trials in hematological malignancies including MM using PD-1 [Pidilizumab (CT-011) or Pembrolizumab] and PD-L1 (Atezolizumab) can be found in www.clinicaltrials.gov and [47-49, 119]. The Table 1 summarizes current recruiting Clinical trials using Lenalidomide combined with anti-PD-1/PD-L1 antibodies in hematological malignancies treatment.

As described above, MM cells express activating NK cell ligands involved in the recognition of NK cells but not in the killing $[12,77-79,82]$. Fionda et al., recently

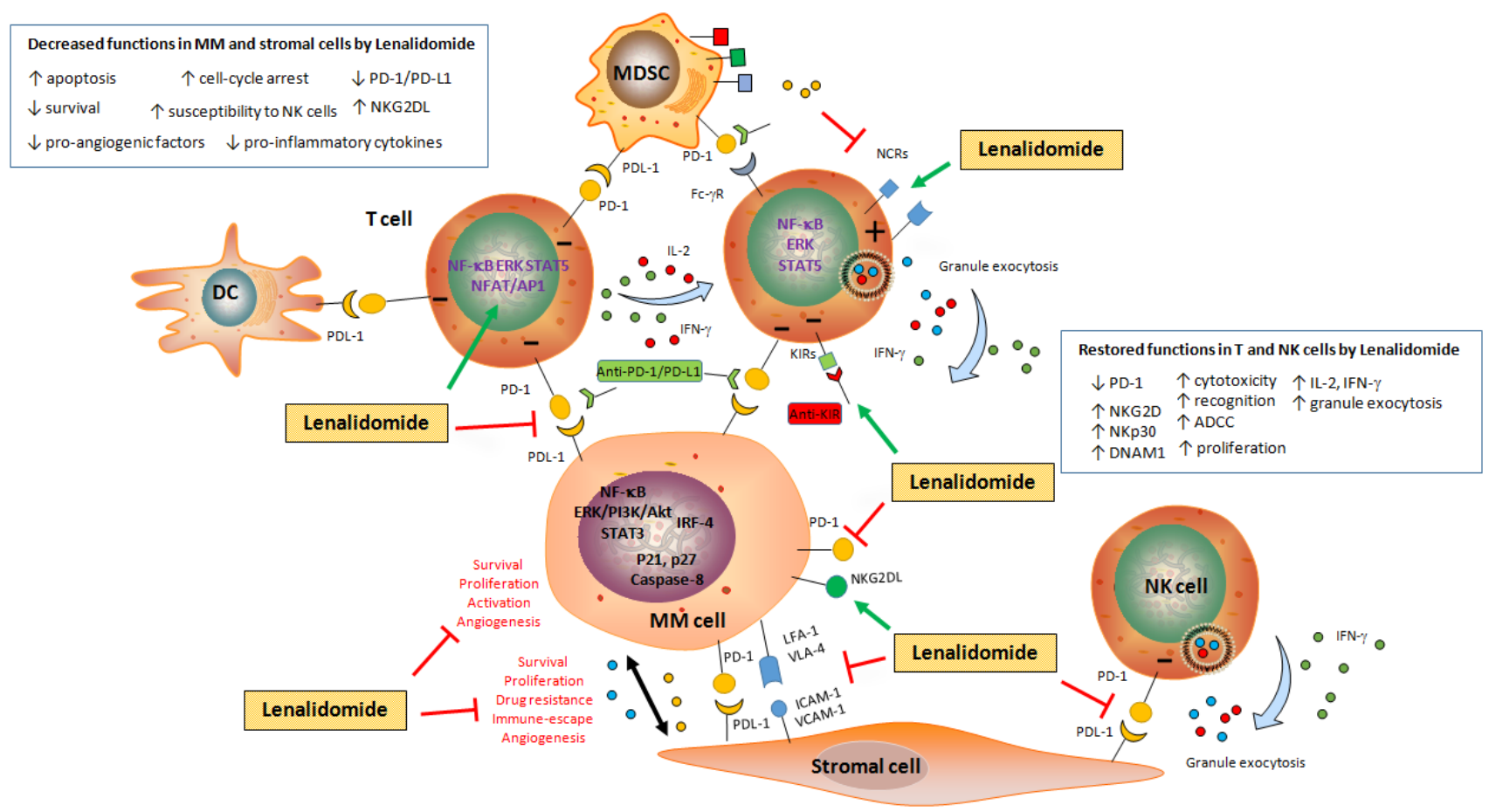

Figure 2: Schematic representation of the impact of Lenalidomide on MM cell survival and immune escape. Lenalidomide induces apoptosis (by increasing p21, p27 and Caspases expression) and impairs survival (by blocking several pathways such as NF- $\mathrm{B}$ and $\mathrm{PI} 3 \mathrm{~K} /$ Akt and inducing cell-cycle arrest) in malignant plasma cells. Additionally, Lenalidomide disrupts the MM/BMSC cell cross-talk, by inhibiting TNF- $\alpha$-induced adhesion molecules (VLA-4, LFA-1, ICAM-1 and VCAM-1) expression on both MM and stromal cells, as well as cytokine secretion (i.e. IL-6, TGF- $\beta$ and IGF-1) and VEGF-mediated angiogenesis. Lenalidomide down-regulates the expression of PD-1 on MM cells and the expression of PD-L1 on both stromal and MM cells, thus inhibiting the vicious circle involved in the impairment of the immune response. Lenalidomide also activates T cells to secrete IL-2 and IFN- $\gamma$, and down-regulates the expression of PD-1 on T and NK cells. This restores NK cell activation, as shown by the increased granule exocytosis (Perforin and Granzyme B) and ADCC, reestablishing cytotoxic functions against tumor cells. In addition, Lenalidomide can be used associated with CT-011 (an anti-PD-1 antibody) to restore immune cell functions. 
Table 1: MM, Multiple Myeloma; MDS,Myelodysplastic Syndrome; NHL, Non-Hodgkin's Lymphoma; FL, Follicular Lymphoma; PD-L1, Programmed Death Ligand-1

\begin{tabular}{|c|c|c|c|c|}
\hline Study & Therapy & Disease & Clinical trial & Status \\
\hline $\begin{array}{l}\text { A Study of Atezolizumab (Anti-Programmed Death Ligand } \\
1 \text { [PD-L1] Antibody) Administered With or Without } \\
\text { Lenalidomide in Participants With Multiple Myeloma } \\
\text { (MM) }\end{array}$ & $\begin{array}{l}\text { Lenalidomide } \\
\text { Atetolizumab }\end{array}$ & MM & NCT02431208 & recruiting \\
\hline $\begin{array}{l}\text { A Study of Pembrolizumab (MK-3475) in Combination } \\
\text { With Standard of Care Treatments in Participants With } \\
\text { Multiple Myeloma (MK-3475-023/KEYNOTE-023) }\end{array}$ & $\begin{array}{l}\text { Lenalidomide } \\
\text { Pembrolizumab } \\
\text { Dexamethasone }\end{array}$ & MM & NCT02036502 & recruiting \\
\hline $\begin{array}{l}\text { Study of Lenalidomide and Dexamethasone With or } \\
\text { Without Pembrolizumab (MK-3475) in Participants With } \\
\text { Newly Diagnosed Treatment Naive Multiple Myeloma } \\
\text { (MK-3475-185/KEYNOTE-185) }\end{array}$ & $\begin{array}{l}\text { Lenalidomide } \\
\text { Dexamethasone } \\
\text { Pembrolizumab }\end{array}$ & MM & NCT02579863 & recruiting \\
\hline $\begin{array}{l}\text { A Trial of Pembrolizumab (MK-3475) in Participants With } \\
\text { Blood Cancers (MK-3475-013)(KEYNOTE-013) }\end{array}$ & $\begin{array}{l}\text { Pembrolizumab } \\
\text { Lenalidomide }\end{array}$ & $\begin{array}{l}\text { MM NHL } \\
\text { Lymphoma } \\
\text { MDS }\end{array}$ & NCT01953692 & recruiting \\
\hline $\begin{array}{l}\text { Phase } 2 \text { Multi-center Study of Anti-PD-1 During } \\
\text { Lymphopenic State After HDT/ASCT for Multiple } \\
\text { Myeloma }\end{array}$ & $\begin{array}{l}\text { Lenalidomide } \\
\text { Pembrolizumab }\end{array}$ & $\mathrm{MM}$ & NCT02331368 & recruiting \\
\hline
\end{tabular}

show that Lenalidomide increases the expression of NKG2D and DNAM-1 ligands on both malignant plasma cells and MM cell lines leading to NK cell interaction and tumor cell killing [120]. Interestingly, authors also demonstrated that the negative modulation of Cerebron, Ikaros (IKZF1), Aiolos (IKZF3) and Interferon-Regulatory Factor (IRF)-4 induced by Lenalidomide was critical to promote the NKG2D ligands expression on MM cells (Figure 2). It is worthy to note that the second-generation of Proteasome Inhibitor Carfilzomib enhanced the sensitivity of MM cells to NK cell-mediated lysis [121]. In addition, Carfilzomib-activated NK cells also displayed an increased cytotoxic granule secretion and cytotoxicity which was correlated to the decreased expression of HLA class I in Carfilzomib-treated MM cells. Unfortunately, the impact of Lenalidomide in HLA class I expression on MM cells and the consequence on anti-tumor response has not been investigated so far.

\section{Lenalidomide restores NK cells cytotoxicity}

Lenalidomide displays immunomodulatory properties by inducing IL- 2 and IFN- $\gamma$ secretion by T cells, Antibody-dependent cell-mediated cytotoxicity (ADCC) as well as NK cell cytotoxic functions [12, 92, 97, 100, 109, 122-125] (Figure 2). In addition, Lenalidomide increases co-stimulatory receptors expression on NK cells, as CD16 and Lymphocytes Function-associated Antigen (LFA-1) [12, 97, 126-129]. Of note, a large heterogeneity exists in in vitro experimental protocols that depends on NK cell sources (total PBMC against purified NK cells), IL-2 and drug concentration, treatment period, targets. Notably, Lenalidomide down-regulates $\mathrm{PD}-1$ expression on $\mathrm{T}$ cells isolated from MM patients, allowing the cytotoxic restoration of their cytotoxicity [127]. Intriguingly, Daguet et al., reported that Lenalidomide affects the secretion of IFN- $\gamma$ by NK cells isolated from healthy donors, and decreases activating receptors expression on NK cells [130]. These findings could explain why Lenalidomide somehow does not directly supports NK cell activation. Interestingly, an opposite effect is observed in CLL patients, since Lenalidomide-stimulated NK cells display a reinforced cytotoxic activity and increased proliferation $[125,131]$ and a repaired immunological synapse, critical for NK cell-mediated tumor surveillance [132]. As already discussed, Benson et al., reported that IPH2101 (an antiKIR) prevents negative signals by KIRs expressed on NK cells [133]. Importantly, IPH2101 can be combined with Lenalidomide which, by improving NK cell activation and increasing NK cell ligands on MM cells, contributes to enhance the in vivo anti-tumor response. Interestingly, the same group have recently published results about the effect of Lenalidomide combined with IPH2101 (without corticosteroids) in relapsed/refractory patients in a Phase I trial [134]. It is important to mention that, although improving MM patients' survival [22, 107, 108, 135-137], Dexamethasone administration could be at detrimental of the immune surveillance against tumor cells [109, $123,125,138,139]$. Advanced findings have in fact demonstrated that Dexamethasone decreases the NKG2D, NKp30 and NKp46 expression on NK cells, as well as the secretion of IL-2 and IFN- $\gamma$ by NK cells [109, 123, 125]. In addition, Dexamethasone decrease IL- 2 and IFN- $\gamma$ secretion in normal PBMCs, as well as activated NK cellrelease of Granzyme B, by antagonizing the stimulatory capacity of Lenalidomide in both T and NK cells [109].

\section{CONCLUSIONS}

The positive impact of Lenalidomide based therapies has been observed in several hematological malignancies. 
For example, NK cells stimulated with Lenalidomide display a reinforced cytotoxic potential in CLL patients $[125,131,132,140]$. In AML patients, NK cells show a reduced target killing since their ability to form an efficient immunological synapse is impaired [141]. Interestingly, lytic granules polarization in the immunological synapse was significantly restored after Lenalidomide treatment. A positive action of Lenalidomide in restoring synapse formation, $\mathrm{ADCC}$, and cytotoxic functions in NK cells have been also reported in B-cell Non Hodgkin Lymphoma patients [142, 143].

By promoting cytokine secretion and activating receptors stimulation on NK cells, associated with an inhibition of the PD-1/PD-L1 axis to disrupt the $\mathrm{MM} /$ stromal cell cross-talk and the immune response exhaustion, Lenalidomide restores NK cell functions in MM patients. Furthermore, Lenalidomide can be combined with monoclonal antibodies (mAbs) such as CT-011 (antiPD-1) [50] to enhance their own positive effect on NK cells. However, certain drugs used in MM therapy such as Dexamethasone interfere with Lenalidomide-induced NK cell activation in vitro. Thus, a more precise understanding of the molecular mechanisms induced by a drug on the immune system should be verified before applying it in MM patients. In conclusion, given the importance of NK cells in cancer surveillance and in autologous SCT in MM patients, Lenalidomide is currently the more complete treatment (alone or combined with anti-PD-1/PD-L1 antibodies or other drugs) able to restore exhausted NK cell cytotoxic functions and to impair MM cell survival and immune-escape. These findings support the fact that Lenalidomide represents an adequate strategy in MM patients to reinforce immune anti-tumor activity.

\section{ACKNOWLEDGMENTS}

This work was supported by FNRS Televie Grants (7.4653.14; 7.4571.15; 7.453516 and 7.4517.14) and Fondation Cancer Luxembourg FC/2016/01.

\section{CONFLICTS OF INTEREST}

The authors indicate no potential conflicts of interest.

\section{Author contributions}

MG designed figures and wrote the manuscript; BJ wrote the manuscript; GB critically reviewed the paper.

\section{REFERENCES}

1. Ljunggren HG, Kärre K. In search of the 'missing self': MHC molecules and NK cell recognition. Immunol Today. 1990; 11:237-44. doi:10.1016/0167-5699(90)90097-S
2. Moretta L, Moretta A. Unravelling natural killer cell function: triggering and inhibitory human NK receptors. EMBO J. 2004; 23:255-59. doi:10.1038/sj.emboj.7600019

3. López-Larrea C, Suárez-Alvarez B, López-Soto A, López-Vázquez A, Gonzalez S. The NKG2D receptor: sensing stressed cells. Trends Mol Med. 2008; 14:179-89. doi:10.1016/j.molmed.2008.02.004

4. Vivier E, Raulet DH, Moretta A, Caligiuri MA, Zitvogel L, Lanier LL, Yokoyama WM, Ugolini S. Innate or adaptive immunity? The example of natural killer cells. Science. 2011; 331:44-49. doi:10.1126/science.1198687

5. Kim SY, Lee H, Han MS, Shim H, Eom HS, Park B, Kong SY. Post-Transplantation Natural Killer Cell Count: A Predictor of Acute Graft-Versus-Host Disease and Survival Outcomes After Allogeneic Hematopoietic Stem Cell Transplantation. Clin Lymphoma Myeloma Leuk. 2016; 16:527-535.e2. doi:10.1016/j.clml.2016.06.013

6. Klingemann H, Grodman C, Cutler E, Duque M, Kadidlo D, Klein AK, Sprague KA, Miller KB, Comenzo RL, Kewalramani T, Yu N, Van Etten RA, McKenna DH. Autologous stem cell transplant recipients tolerate haploidentical related-donor natural killer cell-enriched infusions. Transfusion. 2013; 53:412-18. doi:10.1111/ j.1537-2995.2012.03764.x

7. Porrata LF, Gastineau DA, Padley D, Bundy K, Markovic SN. Re-infused autologous graft natural killer cells correlates with absolute lymphocyte count recovery after autologous stem cell transplantation. Leuk Lymphoma. 2003; 44:997-1000. doi:10.1080/1042819031000077089

8. Ruggeri L, Capanni M, Urbani E, Perruccio K, Shlomchik WD, Tosti A, Posati S, Rogaia D, Frassoni F, Aversa F, Martelli MF, Velardi A. Effectiveness of donor natural killer cell alloreactivity in mismatched hematopoietic transplants. Science. 2002; 295:2097-100. doi:10.1126/ science. 1068440

9. Ruggeri L, Parisi S, Urbani E, Curti A. Alloreactive Natural Killer Cells for the Treatment of Acute Myeloid Leukemia: From Stem Cell Transplantation to Adoptive Immunotherapy. Front Immunol. 2015; 6:479. doi:10.3389/ fimmu.2015.00479

10. Velardi A, Ruggeri L, Mancusi A. Killer-cell immunoglobulin-like receptors reactivity and outcome of stem cell transplant. Curr Opin Hematol. 2012; 19:319-23. doi:10.1097/MOH.0b013e32835423c3

11. Dosani T, Carlsten M, Maric I, Landgren O. The cellular immune system in myelomagenesis: NK cells and T cells in the development of myeloma [corrected] and their uses in immunotherapies. Blood Cancer J. 2015; 5:e306. doi:10.1038/bcj.2015.32

12. Krieg S, Ullrich E. Novel immune modulators used in hematology: impact on NK cells. Front Immunol. 2013; 3:388. doi:10.3389/fimmu.2012.00388

13. Farnault L, Sanchez C, Baier C, Le Treut T, Costello RT. Hematological malignancies escape from NK cell 
innate immune surveillance: mechanisms and therapeutic implications. Clin Dev Immunol. 2012; 2012:421702. doi:10.1155/2012/421702

14. Carbone E, Neri P, Mesuraca M, Fulciniti MT, Otsuki T, Pende D, Groh V, Spies T, Pollio G, Cosman D, Catalano L, Tassone P, Rotoli B, Venuta S. HLA class I, NKG2D, and natural cytotoxicity receptors regulate multiple myeloma cell recognition by natural killer cells. Blood. 2005; 105:251-58. doi:10.1182/blood-2004-04-1422

15. Fauriat C, Mallet F, Olive D, Costello RT. Impaired activating receptor expression pattern in natural killer cells from patients with multiple myeloma. Leukemia. 2006; 20:732-33. doi:10.1038/sj.leu.2404096

16. Girlanda S, Fortis C, Belloni D, Ferrero E, Ticozzi P, Sciorati C, Tresoldi M, Vicari A, Spies T, Groh V, Caligaris-Cappio F, Ferrarini M. MICA expressed by multiple myeloma and monoclonal gammopathy of undetermined significance plasma cells Costimulates pamidronate-activated gammadelta lymphocytes. Cancer Res. 2005; 65:7502-08. doi:10.1158/0008-5472.CAN-050731

17. Jurisic V, Srdic T, Konjevic G, Markovic O, Colovic M. Clinical stage-depending decrease of NK cell activity in multiple myeloma patients. Med Oncol. 2007; 24:312-17. doi:10.1007/s12032-007-0007-y

18. Godfrey J, Benson DM Jr. The role of natural killer cells in immunity against multiple myeloma. Leuk Lymphoma. 2012; 53:1666-76. doi:10.3109/10428194.2012.676175

19. Anderson KC, Carrasco RD. Pathogenesis of myeloma. Annu Rev Pathol. 2011; 6:249-74. doi:10.1146/annurevpathol-011110-130249

20. Kyle RA, Rajkumar SV. Criteria for diagnosis, staging, risk stratification and response assessment of multiple myeloma. Leukemia. 2009; 23:3-9. doi:10.1038/leu.2008.291

21. Palumbo A, Anderson K. Multiple myeloma. N Engl J Med. 2011; 364:1046-60. doi:10.1056/NEJMra1011442

22. Rajkumar SV. Myeloma today: disease definitions and treatment advances. Am J Hematol. 2016; 91:90-100. doi:10.1002/ajh.24236

23. El-Sherbiny YM, Meade JL, Holmes TD, McGonagle D, Mackie SL, Morgan AW, Cook G, Feyler S, Richards SJ, Davies FE, Morgan GJ, Cook GP. The requirement for DNAM-1, NKG2D, and NKp46 in the natural killer cellmediated killing of myeloma cells. Cancer Res. 2007; 67:8444-49. doi:10.1158/0008-5472.CAN-06-4230

24. Costello RT, Boehrer A, Sanchez C, Mercier D, Baier C, Le Treut T, Sébahoun G. Differential expression of natural killer cell activating receptors in blood versus bone marrow in patients with monoclonal gammopathy. Immunology. 2013; 139:338-41. doi:10.1111/imm.12082

25. Konjević G, Vuletić A, Mirjačić Martinović K, Colović N, Čolović M, Jurišić V. Decreased CD161 activating and increased CD158a inhibitory receptor expression on NK cells underlies impaired NK cell cytotoxicity in patients with multiple myeloma. J Clin Pathol. 2016jclinpath-2016-203614.

26. Martínez-Sánchez MV, Periago A, Legaz I, Gimeno L, Mrowiec A, Montes-Barqueros NR, Campillo JA, Bolarin JM, Bernardo MV, López-Álvarez MR, González C, García-Garay MC, Muro M, et al. Overexpression of KIR inhibitory ligands (HLA-I) determines that immunosurveillance of myeloma depends on diverse and strong NK cell licensing. OncoImmunology. 2015; 5:e1093721. doi:10.1080/2162402X.2015.1093721

27. Austin R, Smyth MJ, Lane SW. Harnessing the immune system in acute myeloid leukaemia. Crit Rev Oncol Hematol. 2016; 103:62-77. doi:10.1016/j. critrevonc.2016.04.020

28. Lion E, Willemen Y, Berneman ZN, Van Tendeloo VF, Smits EL. Natural killer cell immune escape in acute myeloid leukemia. Leukemia. 2012; 26:2019-26. doi:10.1038/leu.2012.87

29. Shatnyeva OM, Hansen HP, Reiners KS, Sauer M, Vyas M, von Strandmann EP. DNA damage response and evasion from immunosurveillance in CLL: new options for NK cell-based immunotherapies. Front Genet. 2015; 6:11. doi:10.3389/fgene.2015.00011

30. Reiners KS, Topolar D, Henke A, Simhadri VR, Kessler J, Sauer M, Bessler M, Hansen HP, Tawadros S, Herling M, Krönke M, Hallek M, Pogge von Strandmann E. Soluble ligands for NK cell receptors promote evasion of chronic lymphocytic leukemia cells from NK cell antitumor activity. Blood. 2013; 121:3658-65. doi:10.1182/ blood-2013-01-476606

31. Burger JA, Ghia P, Rosenwald A, Caligaris-Cappio F. The microenvironment in mature B-cell malignancies: a target for new treatment strategies. Blood. 2009; 114:3367-75. doi:10.1182/blood-2009-06-225326

32. Freeman CL, Gribben JG. Immunotherapy in Chronic Lymphocytic Leukaemia (CLL). Curr Hematol Malig Rep. 2016; 11:29-36. doi:10.1007/s11899-015-0295-9

33. Castelli R, Cannavò A, Conforti F, Grava G, Cortelezzi A. Immunomodulatory drugs in multiple myeloma: from molecular mechanisms of action to clinical practice. Immunopharmacol Immunotoxicol. 2012; 34:740-53. doi :10.3109/08923973.2012.658921

34. Rutella S, Locatelli F. Targeting multiple-myelomainduced immune dysfunction to improve immunotherapy outcomes. Clin Dev Immunol. 2012; 2012:196063. doi:10.1155/2012/196063

35. Sponaas AM, Moharrami NN, Feyzi E, Standal T, Holth Rustad E, Waage A, Sundan A. PDL1 Expression on Plasma and Dendritic Cells in Myeloma Bone Marrow Suggests Benefit of Targeted anti PD1-PDL1 Therapy. PLoS One. 2015; 10:e0139867. doi:10.1371/journal. pone. 0139867

36. Leone P, Berardi S, Frassanito MA, Ria R, De Re V, Cicco S, Battaglia S, Ditonno P, Dammacco F, Vacca A, 
Racanelli V. Dendritic cells accumulate in the bone marrow of myeloma patients where they protect tumor plasma cells from CD8+ T-cell killing. Blood. 2015; 126:1443-51. doi:10.1182/blood-2015-01-623975

37. De Keersmaecker B, Fostier K, Corthals J, Wilgenhof S, Heirman C, Aerts JL, Thielemans K, Schots R. Immunomodulatory drugs improve the immune environment for dendritic cell-based immunotherapy in multiple myeloma patients after autologous stem cell transplantation. Cancer Immunol Immunother. 2014; 63:1023-36. doi:10.1007/s00262-014-1571-6

38. Nguyen-Pham TN, Jung SH, Vo MC, Thanh-Tran HT, Lee YK, Lee HJ, Choi NR, Hoang MD, Kim HJ, Lee JJ. Lenalidomide Synergistically Enhances the Effect of Dendritic Cell Vaccination in a Model of Murine Multiple Myeloma. J Immunother. 2015; 38:330-39. doi:10.1097/ CJI.0000000000000097

39. Ribatti D, Moschetta M, Vacca A. Macrophages in multiple myeloma. Immunol Lett. 2014; 161:241-44. doi:10.1016/j. imlet.2013.12.010

40. Mantovani A, Sozzani S, Locati M, Allavena P, Sica A. Macrophage polarization: tumor-associated macrophages as a paradigm for polarized M2 mononuclear phagocytes. Trends Immunol. 2002; 23:549-55. doi:10.1016/S14714906(02)02302-5

41. Asimakopoulos F, Kim J, Denu RA, Hope C, Jensen JL, Ollar SJ, Hebron E, Flanagan C, Callander N, Hematti P. Macrophages in multiple myeloma: emerging concepts and therapeutic implications. Leuk Lymphoma. 2013; 54:211221. doi:10.3109/10428194.2013.778409

42. Kim J, Denu RA, Dollar BA, Escalante LE, Kuether JP, Callander NS, Asimakopoulos F, Hematti P. Macrophages and mesenchymal stromal cells support survival and proliferation of multiple myeloma cells. $\mathrm{Br} \mathrm{J}$ Haematol. 2012; 158:336-46. doi:10.1111/j.1365-2141.2012.09154.x

43. Binsfeld M, Fostier K, Muller J, Baron F, Schots R, Beguin Y, Heusschen R, Caers J. Cellular immunotherapy in multiple myeloma: lessons from preclinical models. Biochim Biophys Acta. 2014; 1846:392-404.

44. Raimondi L, De Luca A, Morelli E, Giavaresi G, Tagliaferri P, Tassone P, Amodio N. MicroRNAs: Novel Crossroads between Myeloma Cells and the Bone Marrow Microenvironment. BioMed Res Int. 2016; 2016:6504593. doi:10.1155/2016/6504593

45. Wang J, De Veirman K, Faict S, Frassanito MA, Ribatti D, Vacca A, Menu E. Multiple myeloma exosomes establish a favorable bone marrow microenvironment with enhanced angiogenesis and immunosuppression. J Pathol. 2016; 239:162-73. doi:10.1002/path.4712

46. Atanackovic D, Luetkens T, Kröger N. Coinhibitory molecule PD-1 as a potential target for the immunotherapy of multiple myeloma. Leukemia. 2014; 28:993-1000. doi:10.1038/leu.2013.310

47. Bryan LJ, Gordon LI. Blocking tumor escape in hematologic malignancies: the anti-PD-1 strategy. Blood Rev. 2015; 29:25-32. doi:10.1016/j.blre.2014.09.004

48. Sehgal A, Whiteside TL, Boyiadzis M. Programmed death-1 checkpoint blockade in acute myeloid leukemia. Expert Opin Biol Ther. 2015; 15:1191-203. doi:10.1517/1 4712598.2015.1051028

49. Vick E, Mahadevan D. Programming the immune checkpoint to treat hematologic malignancies. Expert Opin Investig Drugs. 2016; 25:755-70. doi:10.1080/13543784.2 016.1175433

50. Benson DM Jr, Bakan CE, Mishra A, Hofmeister CC, Efebera Y, Becknell B, Baiocchi RA, Zhang J, Yu J, Smith MK, Greenfield CN, Porcu P, Devine SM, et al. The PD-1/ PD-L1 axis modulates the natural killer cell versus multiple myeloma effect: a therapeutic target for CT-011, a novel monoclonal anti-PD-1 antibody. Blood. 2010; 116:228694. doi:10.1182/blood-2010-02-271874

51. Yousef S, Marvin J, Steinbach M, Langemo A, Kovacsovics T, Binder M, Kröger N, Luetkens T, Atanackovic D. Immunomodulatory molecule PD-L1 is expressed on malignant plasma cells and myeloma-propagating preplasma cells in the bone marrow of multiple myeloma patients. Blood Cancer J. 2015; 5:e285. doi:10.1038/ bcj.2015.7

52. Kuranda K, Berthon C, Dupont C, Wolowiec D, Leleu X, Polakowska R, Jouy N, Quesnel B. A subpopulation of malignant CD34+CD138+B7-H1+ plasma cells is present in multiple myeloma patients. Exp Hematol. 2010; 38:12431. doi:10.1016/j.exphem.2009.11.008

53. Liu J, Hamrouni A, Wolowiec D, Coiteux V, Kuliczkowski K, Hetuin D, Saudemont A, Quesnel B. Plasma cells from multiple myeloma patients express B7-H1 (PD-L1) and increase expression after stimulation with IFN-gamma and TLR ligands via a MyD88-, TRAF6-, and MEK-dependent pathway. Blood. 2007; 110:296-304. doi:10.1182/ blood-2006-10-051482

54. Hallett WH, Jing W, Drobyski WR, Johnson BD. Immunosuppressive effects of multiple myeloma are overcome by PD-L1 blockade. Biol Blood Marrow Transplant. 2011; 17:1133-45. doi:10.1016/j. bbmt.2011.03.011

55. Paiva B, Azpilikueta A, Puig N, Ocio EM, Sharma R, Oyajobi BO, Labiano S, San-Segundo L, Rodriguez A, Aires-Mejia I, Rodriguez I, Escalante F, de Coca AG, et al. PD-L1/PD-1 presence in the tumor microenvironment and activity of PD-1 blockade in multiple myeloma. Leukemia. 2015; 29:2110-13. doi:10.1038/leu.2015.79

56. Rosenblatt J, Glotzbecker B, Mills H, Vasir B, Tzachanis D, Levine JD, Joyce RM, Wellenstein K, Keefe W, Schickler M, Rotem-Yehudar R, Kufe D, Avigan D. PD-1 blockade by CT-011, anti-PD-1 antibody, enhances ex vivo T-cell responses to autologous dendritic cell/myeloma fusion vaccine. J Immunother. 2011; 34:409-18. doi:10.1097/ CJI.0b013e31821ca6ce

57. Wang L, Wang H, Chen H, Wang WD, Chen XQ, Geng 
QR, Xia ZJ, Lu Y. Serum levels of soluble programmed death ligand 1 predict treatment response and progression free survival in multiple myeloma. Oncotarget. 2015; 6:41228-36. 10.18632/oncotarget.5682

58. Pardoll DM. The blockade of immune checkpoints in cancer immunotherapy. Nat Rev Cancer. 2012; 12:252-64. doi:10.1038/nrc3239

59. Xia Y, Jeffrey Medeiros L, Young KH. Signaling pathway and dysregulation of PD1 and its ligands in lymphoid malignancies. Biochim Biophys Acta. 2016; 1865:58-71.

60. Xia Y, Medeiros LJ, Young KH. Immune checkpoint blockade: releasing the brake towards hematological malignancies. Blood Rev. 2016; 30:189-200. doi:10.1016/j. blre.2015.11.003

61. Ramsay AG, Clear AJ, Fatah R, Gribben JG. Multiple inhibitory ligands induce impaired T-cell immunologic synapse function in chronic lymphocytic leukemia that can be blocked with lenalidomide: establishing a reversible immune evasion mechanism in human cancer. Blood. 2012; 120:1412-21. doi:10.1182/blood-2012-02-411678

62. Jang JH, Huang Y, Zheng P, Jo MC, Bertolet G, Zhu MX, Qin L, Liu D. Imaging of Cell-Cell Communication in a Vertical Orientation Reveals High-Resolution Structure of Immunological Synapse and Novel PD-1 Dynamics. J Immunol. 2015; 195:1320-30. doi:10.4049/ jimmunol.1403143

63. Terme M, Ullrich E, Aymeric L, Meinhardt K, Desbois M, Delahaye N, Viaud S, Ryffel B, Yagita H, Kaplanski G, Prévost-Blondel A, Kato M, Schultze JL, et al. IL-18 induces PD-1-dependent immunosuppression in cancer. Cancer Res. 2011; 71:5393-99. doi:10.1158/0008-5472. CAN-11-0993

64. Suen H, Brown R, Yang S, Ho PJ, Gibson J, Joshua D. The failure of immune checkpoint blockade in multiple myeloma with PD-1 inhibitors in a phase 1 study. Leukemia. 2015; 29:1621-22. doi:10.1038/leu.2015.104

65. Suen H, Brown R, Yang S, Weatherburn C, Ho PJ, Woodland N, Nassif N, Barbaro P, Bryant C, Hart D, Gibson J, Joshua D. Multiple myeloma causes clonal T-cell immunosenescence: identification of potential novel targets for promoting tumour immunity and implications for checkpoint blockade. Leukemia. 2016; 30:1716-24. doi:10.1038/leu.2016.84

66. Lesokhin AM, Ansell SM, Armand P, Scott EC, Halwani A, Gutierrez M, Millenson MM, Cohen AD, Schuster SJ, Lebovic D, Dhodapkar M, Avigan D, Chapuy B, et al. Nivolumab in Patients With Relapsed or Refractory Hematologic Malignancy: Preliminary Results of a Phase Ib Study. J Clin Oncol. 2016; 34:2698-704. doi:10.1200/ JCO.2015.65.9789

67. André T, Najar M, Stamatopoulos B, Pieters K, Pradier O, Bron D, Meuleman N, Lagneaux L. Immune impairments in multiple myeloma bone marrow mesenchymal stromal cells. Cancer Immunol Immunother. 2015; 64:213-24. doi:10.1007/s00262-014-1623-y
68. Arnulf B, Lecourt S, Soulier J, Ternaux B, Lacassagne MN, Crinquette A, Dessoly J, Sciaini AK, Benbunan M, Chomienne C, Fermand JP, Marolleau JP, Larghero J. Phenotypic and functional characterization of bone marrow mesenchymal stem cells derived from patients with multiple myeloma. Leukemia. 2007; 21:158-63. doi:10.1038/ sj.leu.2404466

69. Corre J, Mahtouk K, Attal M, Gadelorge M, Huynh A, Fleury-Cappellesso S, Danho C, Laharrague P, Klein $\mathrm{B}$, Rème $\mathrm{T}$, Bourin $\mathrm{P}$. Bone marrow mesenchymal stem cells are abnormal in multiple myeloma. Leukemia. 2007; 21:1079-88.

70. Roccaro AM, Sacco A, Maiso P, Azab AK, Tai YT, Reagan M, Azab F, Flores LM, Campigotto F, Weller E, Anderson KC, Scadden DT, Ghobrial IM. BM mesenchymal stromal cell-derived exosomes facilitate multiple myeloma progression. J Clin Invest. 2013; 123:1542-55. doi:10.1172/ JCI66517

71. Kawano Y, Moschetta M, Manier S, Glavey S, Görgün GT, Roccaro AM, Anderson KC, Ghobrial IM. Targeting the bone marrow microenvironment in multiple myeloma. Immunol Rev. 2015; 263:160-72. doi:10.1111/imr.12233

72. Hao M, Zhang L, An G, Meng H, Han Y, Xie Z, Xu Y, Li C, Yu Z, Chang H, Qiu L. Bone marrow stromal cells protect myeloma cells from bortezomib induced apoptosis by suppressing microRNA-15a expression. Leuk Lymphoma. 2011; 52:1787-94. doi:10.3109/10428194.2011.576791

73. Ponzetta A, Benigni G, Antonangeli F, Sciumè G, Sanseviero E, Zingoni A, Ricciardi MR, Petrucci MT, Santoni A, Bernardini G. Multiple Myeloma Impairs Bone Marrow Localization of Effector Natural Killer Cells by Altering the Chemokine Microenvironment. Cancer Res. 2015; 75:4766-77. doi:10.1158/0008-5472.CAN-15-1320

74. Tamura H, Ishibashi M, Yamashita T, Tanosaki S, Okuyama N, Kondo A, Hyodo H, Shinya E, Takahashi H, Dong H, Tamada K, Chen L, Dan K, Ogata K. Marrow stromal cells induce B7-H1 expression on myeloma cells, generating aggressive characteristics in multiple myeloma. Leukemia. 2013; 27:464-72. doi:10.1038/leu.2012.213

75. Chan AC, Neeson P, Leeansyah E, Tainton K, Quach H, Prince HM, Harrison SJ, Godfrey DI, Ritchie D, Berzins SP. Natural killer T cell defects in multiple myeloma and the impact of lenalidomide therapy. Clin Exp Immunol. 2014; 175:49-58. doi:10.1111/cei.12196

76. Salih HR, Holdenrieder S, Steinle A. Soluble NKG2D ligands: prevalence, release, and functional impact. Front Biosci. 2008; 13:3448-56. doi:10.2741/2939

77. Soriani A, Zingoni A, Cerboni C, Iannitto ML, Ricciardi MR, Di Gialleonardo V, Cippitelli M, Fionda C, Petrucci MT, Guarini A, Foà R, Santoni A. ATM-ATR-dependent up-regulation of DNAM-1 and NKG2D ligands on multiple myeloma cells by therapeutic agents results in enhanced NK-cell susceptibility and is associated with a senescent phenotype. Blood. 2009; 113:3503-11. doi:10.1182/ blood-2008-08-173914 
78. Fionda C, Abruzzese MP, Zingoni A, Soriani A, Ricci B, Molfetta R, Paolini R, Santoni A, Cippitelli M. Nitric oxide donors increase PVR/CD155 DNAM-1 ligand expression in multiple myeloma cells: role of DNA damage response activation. BMC Cancer. 2015; 15:17. doi:10.1186/s12885015-1023-5

79. Fionda C, Malgarini G, Soriani A, Zingoni A, Cecere F, Iannitto ML, Ricciardi MR, Federico V, Petrucci MT, Santoni A, Cippitelli M. Inhibition of glycogen synthase kinase-3 increases NKG2D ligand MICA expression and sensitivity to NK cell-mediated cytotoxicity in multiple myeloma cells: role of STAT3. J Immunol. 2013; 190:6662-72. doi:10.4049/jimmunol.1201426

80. Guillerey C, Ferrari de Andrade L, Vuckovic S, Miles K, Ngiow SF, Yong MC, Teng MW, Colonna M, Ritchie DS, Chesi M, Bergsagel PL, Hill GR, Smyth MJ, Martinet L. Immunosurveillance and therapy of multiple myeloma are CD226 dependent. J Clin Invest. 2015; 125:2077-89. doi:10.1172/JCI77181

81. Rebmann V, Schütt P, Brandhorst D, Opalka B, Moritz T, Nowrousian MR, Grosse-Wilde H. Soluble MICA as an independent prognostic factor for the overall survival and progression-free survival of multiple myeloma patients. Clin Immunol. 2007; 123:114-20. doi:10.1016/j. clim.2006.11.007

82. Jinushi M, Vanneman M, Munshi NC, Tai YT, Prabhala RH, Ritz J, Neuberg D, Anderson KC, Carrasco DR, Dranoff G. MHC class I chain-related protein A antibodies and shedding are associated with the progression of multiple myeloma. Proc Natl Acad Sci USA. 2008; 105:1285-90. doi:10.1073/pnas.0711293105

83. von Lilienfeld-Toal M, Frank S, Leyendecker C, Feyler S, Jarmin S, Morgan R, Glasmacher A, Märten A, SchmidtWolf IG, Brossart P, Cook G. Reduced immune effector cell NKG2D expression and increased levels of soluble NKG2D ligands in multiple myeloma may not be causally linked. Cancer Immunol Immunother. 2010; 59:829-39. doi:10.1007/s00262-009-0807-3

84. Rajkumar SV, Dimopoulos MA, Palumbo A, Blade J, Merlini G, Mateos MV, Kumar S, Hillengass J, Kastritis E, Richardson P, Landgren O, Paiva B, Dispenzieri A, et al. International Myeloma Working Group updated criteria for the diagnosis of multiple myeloma. Lancet Oncol. 2014; 15:e538-48. doi:10.1016/S1470-2045(14)70442-5

85. Kyle RA, Rajkumar SV. Treatment of multiple myeloma: a comprehensive review. Clin Lymphoma Myeloma. 2009; 9:278-88. doi:10.3816/CLM.2009.n.056

86. Rajkumar SV. Treatment of multiple myeloma. Nat Rev Clin Oncol. 2011; 8:479-91. doi:10.1038/nrclinonc.2011.63

87. Palumbo A, Cavallo F, Gay F, Di Raimondo F, Ben Yehuda D, Petrucci MT, Pezzatti S, Caravita T, Cerrato C, Ribakovsky E, Genuardi M, Cafro A, Marcatti M, et al. Autologous transplantation and maintenance therapy in multiple myeloma. N Engl J Med. 2014; 371:895-905. doi:10.1056/NEJMoa1402888
88. Palumbo A, Gay F, Falco P, Crippa C, Montefusco V, Patriarca F, Rossini F, Caltagirone S, Benevolo G, Pescosta N, Guglielmelli T, Bringhen S, Offidani M, et al. Bortezomib as induction before autologous transplantation, followed by lenalidomide as consolidation-maintenance in untreated multiple myeloma patients. J Clin Oncol. 2010; 28:800-07. doi:10.1200/JCO.2009.22.7561

89. Yu J, Venstrom JM, Liu XR, Pring J, Hasan RS, O'Reilly RJ, Hsu KC. Breaking tolerance to self, circulating natural killer cells expressing inhibitory KIR for non-self HLA exhibit effector function after $\mathrm{T}$ cell-depleted allogeneic hematopoietic cell transplantation. Blood. 2009; 113:387584. doi:10.1182/blood-2008-09-177055

90. Jacobs B, Tognarelli S, Poller K, Bader P, Mackensen A, Ullrich E. NK Cell Subgroups, Phenotype, and Functions After Autologous Stem Cell Transplantation. Front Immunol. 2015; 6:583. doi:10.3389/fimmu.2015.00583

91. Htut MG, Palmer J, Spielberger R, Parker PM, Farol LT, Franck A, Jeannet L, Reburiano E, Jimenez V, Duarte L, Dagis A, Sahebi F, Karanes C, et al. NK Cell Recovery and Costimulatory Molecule Profiles After Autologous Hematopoietic Cell Transplantation (HCT) in Multiple Myeloma (MM) Patients. Biol Blood Marrow Transplant. 2013; 19:S203-04. doi:10.1016/j.bbmt.2012.11.224

92. Lioznov M, El-Cheikh J Jr, Hoffmann F, Hildebrandt Y, Ayuk F, Wolschke C, Atanackovic D, Schilling G, Badbaran A, Bacher U, Fehse B, Zander AR, Blaise D, et al. Lenalidomide as salvage therapy after allo-SCT for multiple myeloma is effective and leads to an increase of activated NK (NKp44(+)) and T (HLA-DR(+)) cells. Bone Marrow Transplant. 2010; 45:349-53. doi:10.1038/bmt.2009.155

93. Wolschke C, Stübig T, Hegenbart U, Schönland S, Heinzelmann M, Hildebrandt Y, Ayuk F, Atanackovic D, Dreger P, Zander A, Kröger N. Postallograft lenalidomide induces strong NK cell-mediated antimyeloma activity and risk for T cell-mediated GvHD: results from a phase I/II dose-finding study. Exp Hematol. 2013; 41:134-142.e3. doi:10.1016/j.exphem.2012.10.004

94. Allegra A, Penna G, Alonci A, Russo S, Greve B, Innao V, Minardi V, Musolino C. Monoclonal antibodies: potential new therapeutic treatment against multiple myeloma. Eur J Haematol. 2013; 90:441-68. doi:10.1111/ejh.12107

95. Nijhof IS, Lammerts van Bueren JJ, van Kessel B, Andre P, Morel Y, Lokhorst HM, van de Donk NW, Parren PW, Mutis T. Daratumumab-mediated lysis of primary multiple myeloma cells is enhanced in combination with the human anti-KIR antibody IPH2102 and lenalidomide. Haematologica. 2015; 100:263-68. doi:10.3324/ haematol.2014.117531

96. Chanan-Khan AA, Swaika A, Paulus A, Kumar SK, Mikhael JR, Rajkumar SV, Dispenzieri A, Lacy MQ. Pomalidomide: the new immunomodulatory agent for the treatment of multiple myeloma. Blood Cancer J. 2013; 3:e143. doi:10.1038/bcj.2013.38

97. Quach H, Ritchie D, Stewart AK, Neeson P, Harrison 
S, Smyth MJ, Prince HM. Mechanism of action of immunomodulatory drugs (IMiDS) in multiple myeloma. Leukemia. 2010; 24:22-32. doi:10.1038/leu.2009.236

98. Hideshima T, Chauhan D, Shima Y, Raje N, Davies FE, Tai YT, Treon SP, Lin B, Schlossman RL, Richardson P, Muller G, Stirling DI, Anderson KC. Thalidomide and its analogs overcome drug resistance of human multiple myeloma cells to conventional therapy. Blood. 2000; 96:2943-50.

99. Harousseau JL. Thalidomide in multiple myeloma: past, present and future. Future Oncol. 2006; 2:577-89. doi:10.2217/14796694.2.5.577

100. Davies FE, Raje N, Hideshima T, Lentzsch S, Young G, Tai YT, Lin B, Podar K, Gupta D, Chauhan D, Treon SP, Richardson PG, Schlossman RL, et al. Thalidomide and immunomodulatory derivatives augment natural killer cell cytotoxicity in multiple myeloma. Blood. 2001; 98:210-16. doi:10.1182/blood.V98.1.210

101. Lacy MQ, Hayman SR, Gertz MA, Dispenzieri A, Buadi F, Kumar S, Greipp PR, Lust JA, Russell SJ, Dingli D, Kyle RA, Fonseca R, Bergsagel PL, et al. Pomalidomide (CC4047) plus low-dose dexamethasone as therapy for relapsed multiple myeloma. J Clin Oncol. 2009; 27:500814. doi:10.1200/JCO.2009.23.6802

102. Larocca A, Montefusco V, Bringhen S, Rossi D, Crippa C, Mina R, Galli M, Marcatti M, La Verde G, Giuliani N, Magarotto V, Guglielmelli T, Rota-Scalabrini D, et al. Pomalidomide, cyclophosphamide, and prednisone for relapsed/refractory multiple myeloma: a multicenter phase 1/2 open-label study. Blood. 2013; 122:2799-806. doi:10.1182/blood-2013-03-488676

103. Semeraro M, Vacchelli E, Eggermont A, Galon J, Zitvogel L, Kroemer G, Galluzzi L. Trial Watch: lenalidomide-based immunochemotherapy. OncoImmunology. 2013; 2:e26494. doi:10.4161/onci.26494

104. Zagouri F, Terpos E, Kastritis E, Dimopoulos MA. An update on the use of lenalidomide for the treatment of multiple myeloma. Expert Opin Pharmacother. 2015; 16:1865-77. doi:10.1517/14656566.2015.1067681

105. Paiva B, Mateos MV, Sanchez-Abarca LI, Puig N, Vidriales MB, López-Corral L, Corchete LA, Hernandez MT, Bargay J, de Arriba F, de la Rubia J, Teruel AI, Giraldo P, et al, and Spanish Myeloma Group / Program Study and Treatment of Hematological Malignancies cooperative study groups. Immune status of high-risk smoldering multiple myeloma patients and its therapeutic modulation under LenDex: a longitudinal analysis. Blood. 2016; 127:1151-62. doi:10.1182/blood-2015-10-662320

106. Cavo M, Tacchetti P, Patriarca F, Petrucci MT, Pantani L, Galli M, Di Raimondo F, Crippa C, Zamagni E, Palumbo A, Offidani M, Corradini P, Narni F, et al, and GIMEMA Italian Myeloma Network. Bortezomib with thalidomide plus dexamethasone compared with thalidomide plus dexamethasone as induction therapy before, and consolidation therapy after, double autologous stem-cell transplantation in newly diagnosed multiple myeloma: a randomised phase 3 study. Lancet. 2010; 376:2075-85. doi:10.1016/S0140-6736(10)61424-9

107. Dimopoulos M, Spencer A, Attal M, Prince HM, Harousseau JL, Dmoszynska A, San Miguel J, Hellmann A, Facon T, Foà R, Corso A, Masliak Z, Olesnyckyj M, et al, and Multiple Myeloma (010) Study Investigators. Lenalidomide plus dexamethasone for relapsed or refractory multiple myeloma. N Engl J Med. 2007; 357:2123-32. doi:10.1056/NEJMoa070594

108. Mateos MV, Hernández MT, Giraldo P, de la Rubia J, de Arriba F, López Corral L, Rosiñol L, Paiva B, Palomera L, Bargay J, Oriol A, Prosper F, López J, et al. Lenalidomide plus dexamethasone for high-risk smoldering multiple myeloma. N Engl J Med. 2013; 369:438-47. doi:10.1056/ NEJMoa1300439

109. Gandhi AK, Kang J, Capone L, Parton A, Wu L, Zhang LH, Mendy D, Lopez-Girona A, Tran T, Sapinoso L, Fang W, Xu S, Hampton G, et al. Dexamethasone synergizes with lenalidomide to inhibit multiple myeloma tumor growth, but reduces lenalidomide-induced immunomodulation of T and NK cell function. Curr Cancer Drug Targets. 2010; 10:155-67. doi:10.2174/156800910791054239

110. Davies F, Baz R. Lenalidomide mode of action: linking bench and clinical findings. Blood Rev. 2010 (Suppl 1); 24:S13-19. doi:10.1016/S0268-960X(10)70004-7

111. Zhu D, Corral LG, Fleming YW, Stein B. Immunomodulatory drugs Revlimid (lenalidomide) and CC-4047 induce apoptosis of both hematological and solid tumor cells through NK cell activation. Cancer Immunol Immunother. 2008; 57:1849-59. doi:10.1007/s00262-0080512-7

112. Görgün G, Samur MK, Cowens KB, Paula S, Bianchi G, Anderson JE, White RE, Singh A, Ohguchi H, Suzuki R, Kikuchi S, Harada T, Hideshima T, et al. Lenalidomide Enhances Immune Checkpoint Blockade-Induced Immune Response in Multiple Myeloma. Clin Cancer Res. 2015; 21:4607-18. doi:10.1158/1078-0432.CCR-15-0200

113. Kearl TJ, Jing W, Gershan JA, Johnson BD. Programmed death receptor-1/programmed death receptor ligand-1 blockade after transient lymphodepletion to treat myeloma. J Immunol. 2013; 190:5620-28. doi:10.4049/ jimmunol.1202005

114. Anderson AC, Joller N, Kuchroo VK. Lag-3, Tim-3, and TIGIT: Co-inhibitory Receptors with Specialized Functions in Immune Regulation. Immunity. 2016; 44:989-1004. doi:10.1016/j.immuni.2016.05.001

115. Chung DJ, Pronschinske KB, Shyer JA, Sharma S, Leung S, Curran SA, Lesokhin AM, Devlin SM, Giralt SA, Young JW. T-cell Exhaustion in Multiple Myeloma Relapse after Autotransplant: Optimal Timing of Immunotherapy. Cancer Immunol Res. 2016; 4:61-71. doi:10.1158/2326-6066.CIR15-0055

116. Ray A SD, Song Y, Chauhan D, Anderson KC. Combination of Anti-PD-L1 Antibody with IMiDs Immunomodulatory Drugs, HDAC Inhibitor ACY-1215, Bortezomib, or Toll- 
like Receptor 9 Agonist Enhances Anti-Tumor Immunity and Cytotoxicity in Multiple Myeloma Blood. 2015; 652. Myeloma: Pathophysiology and Pre-Clinical Studies, excluding Therapy: Poster II.

117. Miguel JS, Shah JJ, Ocio EM, Rodriguez-Otero P, Reece D, Munshi NC, Avigan DE, Ge Y, Balakumaran A, Marinello P, Orlowski RZ, Siegel DS. Pembrolizumab in Combination with Lenalidomide and Low-Dose Dexamethasone for Relapsed/Refractory Multiple Myeloma (RRMM): Keynote-023. Blood. 2015.

118. Badros AZ, Ma N, Rapoport AP, Lederer E, Philip S, Lesho P, Dell C, Hardy NM, Yared J, Goloubeva O, Singh Z. A Phase II Study of Anti PD-1 Antibody Pembrolizumab, Pomalidomide and Dexamethasone in Patients with Relapsed/Refractory Multiple Myeloma (RRMM). Blood. 2015; 126.

119. Ohaegbulam KC, Assal A, Lazar-Molnar E, Yao Y, Zang $X$. Human cancer immunotherapy with antibodies to the PD-1 and PD-L1 pathway. Trends Mol Med. 2015; $21: 24$ 33. doi:10.1016/j.molmed.2014.10.009

120. Fionda C, Abruzzese MP, Zingoni A, Cecere F, Vulpis E, Peruzzi G, Soriani A, Molfetta R, Paolini R, Ricciardi MR, Petrucci MT, Santoni A, Cippitelli M. The IMiDs targets IKZF-1/3 and IRF4 as novel negative regulators of NK cell-activating ligands expression in multiple myeloma. Oncotarget. 2015; 6:23609-30. doi:10.18632/ oncotarget.4603

121. Yang G, Gao M, Zhang Y, Kong Y, Gao L, Tao Y, Han Y, Wu H, Meng X, Xu H, Zhan F, Wu X, Shi J. Carfilzomib enhances natural killer cell-mediated lysis of myeloma linked with decreasing expression of HLA class I. Oncotarget. 2015; 6:26982-94. doi:10.18632/ oncotarget. 4831

122. Görgün G, Calabrese E, Soydan E, Hideshima T, Perrone G, Bandi M, Cirstea D, Santo L, Hu Y, Tai YT, Nahar S, Mimura N, Fabre C, et al. Immunomodulatory effects of lenalidomide and pomalidomide on interaction of tumor and bone marrow accessory cells in multiple myeloma. Blood. 2010; 116:3227-37. doi:10.1182/blood-2010-04-279893

123. Carter CR, Feyler S, Smalle N, Scott GB, Parrish C, Cullen K, Kallmeyer C, Wood PM, Cook G. Effect of combined dexamethasone/lenalidomide therapy on NK cell-receptor levels in myeloma patients. Blood. 2011; 118:6465-66. doi:10.1182/blood-2011-08-372680

124. Hallett WH, Ames E, Motarjemi M, Barao I, Shanker A, Tamang DL, Sayers TJ, Hudig D, Murphy WJ. Sensitization of tumor cells to NK cell-mediated killing by proteasome inhibition. J Immunol. 2008; 180:163-70. doi:10.4049/ jimmunol.180.1.163

125. Hsu AK, Quach H, Tai T, Prince HM, Harrison SJ, Trapani JA, Smyth MJ, Neeson P, Ritchie DS. The immunostimulatory effect of lenalidomide on NKcell function is profoundly inhibited by concurrent dexamethasone therapy. Blood. 2011; 117:1605-13. doi:10.1182/blood-2010-04-278432
126. Jungkunz-Stier I, Zekl M, Stühmer T, Einsele H, Seggewiss-Bernhardt R. Modulation of natural killer cell effector functions through lenalidomide/dasatinib and their combined effects against multiple myeloma cells. Leuk Lymphoma. 2014; 55:168-76. doi:10.3109/10428194.201 3.794270

127. Luptakova K, Rosenblatt J, Glotzbecker B, Mills H, Stroopinsky D, Kufe T, Vasir B, Arnason J, Tzachanis D, Zwicker JI, Joyce RM, Levine JD, Anderson KC, et al. Lenalidomide enhances anti-myeloma cellular immunity. Cancer Immunol Immunother. 2013; 62:39-49. doi:10.1007/s00262-012-1308-3

128. Hayashi T, Hideshima T, Akiyama M, Podar K, Yasui H, Raje N, Kumar S, Chauhan D, Treon SP, Richardson $\mathrm{P}$, Anderson KC. Molecular mechanisms whereby immunomodulatory drugs activate natural killer cells: clinical application. Br J Haematol. 2005; 128:192-203. doi:10.1111/j.1365-2141.2004.05286.x

129. Lagrue K, Carisey A, Morgan DJ, Chopra R, Davis DM. Lenalidomide augments actin remodeling and lowers NK-cell activation thresholds. Blood. 2015; 126:50-60. doi:10.1182/blood-2015-01-625004

130. Dauguet N, Fournié JJ, Poupot R, Poupot M. Lenalidomide down regulates the production of interferon-gamma and the expression of inhibitory cytotoxic receptors of human Natural Killer cells. Cell Immunol. 2010; 264:163-70. doi:10.1016/j.cellimm.2010.06.003

131. Acebes-Huerta A, Huergo-Zapico L, Gonzalez-Rodriguez AP, Fernandez-Guizan A, Payer AR, López-Soto A, Gonzalez S. Lenalidomide induces immunomodulation in chronic lymphocytic leukemia and enhances antitumor immune responses mediated by NK and CD4 T cells. BioMed Res Int. 2014; 2014:265840. doi: $10.1155 / 2014 / 265840$

132. Shanafelt TD, Ramsay AG, Zent CS, Leis JF, Tun HW, Call TG, LaPlant B, Bowen D, Pettinger A, Jelinek DF, Hanson CA, Kay NE. Long-term repair of T-cell synapse activity in a phase II trial of chemoimmunotherapy followed by lenalidomide consolidation in previously untreated chronic lymphocytic leukemia (CLL). Blood. 2013; 121:4137-41. doi:10.1182/blood-2012-12-470005

133. Benson DM Jr, Bakan CE, Zhang S, Collins SM, Liang J, Srivastava S, Hofmeister CC, Efebera Y, Andre P, Romagne F, Bléry M, Bonnafous C, Zhang J, et al. IPH2101, a novel anti-inhibitory KIR antibody, and lenalidomide combine to enhance the natural killer cell versus multiple myeloma effect. Blood. 2011; 118:6387-91. doi:10.1182/ blood-2011-06-360255

134. Benson DM Jr, Cohen AD, Jagannath S, Munshi NC, Spitzer G, Hofmeister CC, Efebera YA, Andre P, Zerbib R, Caligiuri MA. A Phase I Trial of the Anti-KIR Antibody IPH2101 and Lenalidomide in Patients with Relapsed/ Refractory Multiple Myeloma. Clin Cancer Res. 2015; 21:4055-61. doi:10.1158/1078-0432.CCR-15-0304

135. Benboubker L, Dimopoulos MA, Dispenzieri A, Catalano J, 
Belch AR, Cavo M, Pinto A, Weisel K, Ludwig H, Bahlis N, Banos A, Tiab M, Delforge M, et al, and FIRST Trial Team. Lenalidomide and dexamethasone in transplantineligible patients with myeloma. N Engl J Med. 2014; 371:906-17. doi:10.1056/NEJMoa1402551

136. Musto P, Simeon V, Martorelli MC, Petrucci MT, Cascavilla N, Di Raimondo F, Caravita T, Morabito F, Offidani M, Olivieri A, Benevolo G, Mina R, Guariglia R, et al. Lenalidomide and low-dose dexamethasone for newly diagnosed primary plasma cell leukemia. Leukemia. 2014; 28:222-25. doi:10.1038/leu.2013.241

137. Palumbo A, Dimopoulos M, San Miguel J, Harousseau JL, Attal M, Hussein M, Knop S, Ludwig H, von LilienfeldToal M, Sonneveld P. Lenalidomide in combination with dexamethasone for the treatment of relapsed or refractory multiple myeloma. Blood Rev. 2009; 23:87-93. doi:10.1016/j.blre.2008.07.003

138. Hsu A, Ritchie DS, Neeson P. Are the immunostimulatory properties of Lenalidomide extinguished by co-administration of Dexamethasone? OncoImmunology. 2012; 1:372-74. doi:10.4161/onci.18963

139. Mitsiades CS. How "immunomodulatory" are IMIDs? Blood. 2011; 117:1440-41. doi:10.1182/ blood-2010-11-317156
140. Ramsay AG, Evans R, Kiaii S, Svensson L, Hogg N, Gribben JG. Chronic lymphocytic leukemia cells induce defective LFA-1-directed T-cell motility by altering Rho GTPase signaling that is reversible with lenalidomide. Blood. 2013; 121:2704-14. doi:10.1182/ blood-2012-08-448332

141. Khaznadar Z, Henry G, Setterblad N, Agaugue S, Raffoux E, Boissel N, Dombret H, Toubert A, Dulphy N. Acute myeloid leukemia impairs natural killer cells through the formation of a deficient cytotoxic immunological synapse. Eur J Immunol. 2014; 44:3068-80. doi:10.1002/ eji.201444500

142. Gribben JG, Fowler N, Morschhauser F. Mechanisms of Action of Lenalidomide in B-Cell Non-Hodgkin Lymphoma. J Clin Oncol. 2015; 33:2803-11. doi:10.1200/ JCO.2014.59.5363

143. Kritharis A, Coyle M, Sharma J, Evens AM. Lenalidomide in non-Hodgkin lymphoma: biological perspectives and therapeutic opportunities. Blood. 2015; 125:2471-76. doi:10.1182/blood-2014-11-567792 